\title{
Science Medals of Great Britain, Ireland, and the Dominions.
}

A $\mathrm{S}$ a supplement to the issue of NATURE of A Nov. 15, 1930, we published an article on medals awarded for scientific achievement, and brief classified statements relating to the various medals in the gift of institutions of the British Empire. The difficulty of making the list exhaustive was obvious, and we print below particulars of further awards to which our attention has been directed.

\section{General.}

Royal Society of Western Australia, Perth.

Society's Gold Medal.-Arising from the com. memoration of the centenary of birth of Lord Kelvin, in 1924, the Society decided to institute a gold medal for award from time to time for distinguished work in science connected with Western Australia. The entire initial cost was borne by voluntary subscriptions. The award is made on a recommendation by a medal committee of five members, and normally at four-yearly intervals. The first allotment was in 1925 , to Dr. W. J. Hancock, for pioneer research in radiology; that for 1929 was given Dr. E. S. Simpson, government mineralogist and analyst. The obverse of the medal bears the bust of Lord Kelvin.

Royal Numismatic Society of London.

Society's Medal.-Founded in 1883, and awarded annually or otherwise in silver or bronze for distinguished services to numismatic science; the recipient may be of either sex, and there is no restriction as to nationality. The first allotment was made to Charles Roach Smith, the eminent antiquary; that for 1930 to Mr. P. H. Webb, president of the Society.

\section{British Numismatic Society.}

Saltus Gold Medal.-Founded in 1910 by Mr. John Sanford Saltus, of New York, a vice-president. Awarded triennially to " the member of the Society whose paper or papers appearing in the Society's publications shall receive the highest number of votes from the members, as being in their opinion the best in the interests of numismatic science". Allotment was made in 1929 to Mr. J. S. ShirleyFox.

\section{University of Melbourne.}

David Syme Research Medal and Prize.-(Mr. E. 0. Hercus, 16 Melbourne Place, Cambridge, directed our attention to the omission of this prize. Strictly, the original series comprised the awards of medals made by scientific academies and societies, but the following account will be of interest.)

Founded by the gift of $£ 3000$ by David Syme for the purpose of encouraging in Australia the carrying out of research work in biology, chemistry, geology, and natural philosophy. The award takes the form of the annual bestowal of a gold medal and gift of $£ 125$ for a thesis based upon original work in the departments of science mentioned above, but preferably in connexion with the material and industrial development of Australia. The thesis must either have been published not more than two years before an allotment, or published afterwards in such a manner as shall satisfy the council. The prize is open to any person who has been resident in Australia for not less than five years out of the seven years immediately preceding that in which the prize is offered. No professor in an Australian university and no head of a scientific department under any Australian authority is eligible.

\section{Physical and Mathematical Sciences. Institute of Actuaries.}

Institute Gold Medal.-In 1920 it was decided to establish a gold medal in recognition of any paper or treatise of outstanding originality in actuarial science, the award not to be restricted as to nationality or sex.

N.B.-No award of this medal has been made so far, but it should be mentioned that in 1927 and in 1929 special gold medals were struck, and bestowed respectively upon two distinguished exponents of actuarial science.

\section{British Astronomical Association.}

Walter Goodacre Gold Medal.-Founded in 1929 through a fund provided by Mr. Walter Goodacre, a past president, and for award to members in recognition of contributions to the progress of astronomy, special regard being paid to work communicated to the Association. An award is made at intervals of not less than two years nor more than four years. The first allotment was made in 1930 to the Rev. T. E. R. Phillips.

Institution of Givil Engineers of Ireland.

Mullins Medal.-The Institution awards medals (or premiums) annually under the terms of a bequest by Mr. M. B. Mullins, president in 1859-61. The medals may be of gold or silver, and refer in bestowal to meritorious papers read before the Institution. The obverse of the medal bears the head of Mullins.

\section{Institute of Fuel.}

Melchett Medal.-Inaugurated in 1930 by Lord Melchett, founder-president (1927) of the Institute, to mark the completion of his period of office, for annual award. It is struck in bronze, and awarded to such person, whether a member of the Institute of Fuel or otherwise, as in the opinion of the council has done either original research or professional, administrative, or constructive work of an outstanding character involving the scientific preparation or use of fuel, provided the results of such work have been made available within recent date for the benefit of the community. The allotment is without restriction as to the nationality of the recipient. The first award was made to Dr. Kurt Rummell, principal of the Wärmestelle, Düsseldorf. It is the intention of the council to invite the recipient each year to give a Melchett lecture, follow. ing the presentation of the medal.

No. 3201, VoL. 127] 
Society of Glass Technology, Sheffield.

Frank Wood Medal.-In 1919, the Society, in order to commemorate the services of Mr. Frank Wood, who was the first president, to the glass industry and glass technology, inaugurated a fund and decided to found a medal in bronze; the award to be placed in the gift of the University of Sheffield, and allotted annually to students in the Glass Technology Department. The University holds the fund as trustee. The design of the medal was entrusted to Mr. P. Metcalfe, Royal College of Art, South Kensington.

\section{British Horological Institute.}

Institute's Gold Medal.--The Institute was established in 1858. In 1928 a gold medal was founded for annual award, at the discretion of the council, for the greatest advance in the science of horology, or some achievement of outstanding merit beneficial to the science or practice of time measurement. The first recipient was the Astronomer Royal, Sir Frank Dyson. The reverse of the medal carries the inscription : "For having improved horology by practice and enriched it with learning".

\section{British Institute of Radiology.}

Silvanus Thompson Medal.-Founded in 1918, in association with a memorial lecture, and in commemoration of Prof. Silvanus P. Thompson, F.R.S., the first president of the Röntgen Society. Distinguished workers in radiology or allied subjects, of any nationality, may be invited to deliver the lecture, and, so far as possible, choice falls alternately on a medical and a non-medical man. The medal is struck in bronze and bears the bust of Thompson. An honorarium is attached to the lectureship.

Mackenzie Davidson Medal.-Founded in 1920, in association with a memorial lecture, and in commemoration of Sir James Mackenzie Davidson, a pioneer in British radiology. Distinguished workers in radiology or allied subjects, of any nationality, may be invited to deliver the lecture, and, so far as possible, choice falls alternately on a medical and a non-medical man. The medal is struck in bronze, and bears the bust of Mackenzie Davidson. The regulations provide that the choice of lecturer shall be made each year by a joint selection committee appointed by the Institute and the Electro-Therapeutic Section of the Royal Society of Medicine. An honorarium is attached to the lectureship.

Society of Radiographers, London.

Reid Medal.--Instituted as a memorial of the services of Sir Archibald Reid. Struck in silver, it is awarded annually in competition amongst members of the Society for radiographic films of merit, applicable to selected subjects which are chosen by the council. The obverse of the medal bears the bust of Reid.

Australian Chemical Institute, Sydney.

Smith Memorial Medal.-Founded in 1929 to perpetuate the memory of Henry George Smith, one of the foundation officers of the Institute and a pioneer in research into the chemistry of the Australian eucalypts. The leading Australian scientific societies were represented on the memorial committee, and contributions to the fund were received from each State in the Commonwealth, It is struck in bronze, and awarded annually to that person who has, in the opinion of council, contributed meritorious service to the development of chemical science. The first allotment (1929) was made to Dr. A. C. D. Rivett, of Melbourne, for research work published during the ten preceding years.

Rennie Memorial Medal.-In the course of 1930 , members of the Institute established a fund to found a bronze medal in memory of Dr. Rennie, Angas professor of chemistry in the University of Adelaide for more than forty years. He was actively associated with the formation of the Institute, and at one period was its president. It is proposed to award the medal annually, among the younger members of the Institute, for research work.

\section{Biological Sciences (Including Geology AND GEOGRAPHY).}

\section{Royal Society of Tropical Medicine and Hygiene.}

Chalmers Memorial Gold Medal.--Founded in 1921 by Mrs. Chalmers, widow of Dr. Albert John Chalmers, author of numerous works on tropical medicine and hygiene, and student of the hygiene of the tropics. The award is made biennially, and bestowal is in recognition of research of outstanding merit contributing to the sciences of tropical medicine or tropical hygiene. There are no restrictions as regards nationality, sex, or profession. The medal bears on the obverse the head of Dr. Chalmers; on the reverse a representation of Anopheles costalis, and below, a spray of the cinchona plant. The first award was made in 1923 to M. Roubaud, Pasteur Institute, Paris.

Manson Medal.-A fund had been subscribed in 1921 by friends and admirers of Sir Patrick Manson, in all parts of the world, with the view of obtaining a memorial portrait. A balance in the fund being available, a bronze medal was founded in memory of Manson's fruitful work and influence in the field of tropical medicine and hygiene. The capital sum, with the allotment of the medal, was vested in the council of the Royal Society of Tropical Medicine and Hygiene. An award is made triennially to the living author of such original work in any branch of tropical medicine or tropical hygiene as may appear to be deserving of the honour. There is no restriction as to the age, sex, profession, or nationality of the author. The obverse of the medal bears the bust of Manson. The first recipient was Sir David Bruce; the last (1929), Sir Ronald Ross.

Royal Army Medical and Allied Services.

North Persian Forces Memorial Medal.-In 1921 a fund was raised by certain officers of the Royal Army Medical Corps and Indian Medical Service who took part in the withdrawal of the North

No. 3201, VoL. 127] 
Persian Forces and their subsequent dissolution. Struck in silver, a medal is awarded annually for the best paper on tropical medicine or hygiene published in any journal during the preceding twelve months by a medical officer, of less than twelve years' service, of the Royal Navy, Royal Army
Medical Corps, Royal Air Force, Indian Medical Service, or of the Colonial Medical Service. A Memorial Committee determines the attainment of a standard of merit. The first award was made in 1923. The recipient for 1929 was Capt. H. W. Mulligan, Indian Medical Service.

\section{Obituary.}

\section{Dr. Alfred P. Maudslay.} $A^{\text {LFRED PERCIVAL MAUDSLAY passed away }}$ peacefully in his sleep on Jan. 22 , in his eightyfirst year, at Morney Cross, near Hereford. Born on Mar. 18, 1850, at Lower Norwood Lodge, he attended first a boarding school at Tunbridge Wells and then went to Harrow. He was keen in all forms of sport, particularly fishing, and shot for his school in the winning team for the Ashburton Shield. Leaving school, he proceeded to Trinity Hall, Cambridge, of which he was made an honorary fellow in 1923. A visit to the West Indies was made in 1872, and from Panama and Guatemala he went north to San Francisco, on his way to New York, and there met his future wife, a daughter of Governor Morris of Old Morrisania, New York. The following year, accompanied by his brother, he visited Iceland, making the ardous trip round the island, but he also tells of many pleasant days fly-fishing.

After taking his degree in 1875, Maudslay went to Trinidad, where he accepted his first appointment as private secretary to H.E. the Governor. He next acted in a similar capacity to the Governor of Queensland. Joining the staff of Sir Arthur Gordon as private secretary, he went to Fiji, becoming in turn Acting Colonial Secretary to Fiji, Deputy Commissioner to Tonga and Samoa, and Acting Consul-General for the Western Pacific. In 1876 he accompanied Lady Gordon to New Zealand, where he spent some months, crossing into the then prohibited Maori Territory. Returning to Fiji, he went to live on Tonga as Deputy Commissioner. He left these Pacific islands in 1879 , but it was only last year that he published a delightful autobiography of that period in "Life in the Pacific Fifty Years Ago".

Maudslay in his visit to Guatemala was so struck with the Maya ruins he had seen there that he decided to give up his diplomatic career and devote his life to exploration in Central America. To that country and Mexico he made at least seven expeditions, visiting, clearing, measuring, photographing, and plotting all the then known Mayan ruins, and the results of these expeditions appeared in 1889 in the "Biologia CentraliAmericana ... Archæology". By this monumental work he laid the foundation of Maya research, which has since been enthusiastically taken up by German and American scholars. This, unfortunately, cannot be said of Great Britain; his priceless collection of 'squeezes' and moulds (which had cost him $£ 10,000$ ) he presented to the nation; but they lay neglected, falling to pieces and eaten by rats, for upwards of thirty-five years in the vaults of the South Kensington Museum, until they were rescued in 1923 by Capt. Joyce on behalf of the British Museum. There they were pieced together and restored, and casts made and set up in a room to themselves, as they deserve, and now form the finest collection of Maya casts in the world. There is an interesting and well illustrated account of these casts compiled by Dr. Maudslay and Capt. Joyce. Maya expeditions to British Honduras, under the direction of the British Museum, have gone out annually since 1926, but the lack of public interest has made expenditure a first consideration, and were it not for the generous help of a few private individuals who supplement the small British Museum grant, it is doubtful if many more expeditions can go out without the help of the United States.

When Maudslay made his seventh expedition to Central America, he was accompanied by his wife, and the result was the joint publication of "A Glimpse at Guatemala" in 1899. This charming and beautiful book is printed on hand-made paper and profusely illustrated with photogravures, coloured plates, and chromo-lithographs. The next work from his pen was a translation, with introduction and notes, of Bernal Diaz" "The True History of the Conquest of New Spain " for the Hakluyt Society, and it ranks among the finest of that Society's publications.

In the summer of 1912, the eighteenth International Congress of Americanists met in London under the auspices of the Royal Anthropological Institute, when Maudslay was president; and when the Congress visited Oxford the honorary degree of D.Sc. was conferred on him for his contributions to Mexican and Mayan archæology. Cambridge also honoured him by conferring on him the honorary degree of Sc.D.

In 1915 Maudslay was one of the joint secretaries of the Royal Geographical Society, in which he took a keen interest, specially at the time when the Society moved from its cramped quarters in Savile Row to Lowther Lodge. In 1928 Maudslay published a popular edition of "The Discovery and Conquest of Mexico", with introduction and notes.

It was in 1905, in Mexico City, that the present writer had the pleasure of first meeting Dr. Maudslay, at a luncheon at the British Legation, sitting next to him ; the conversation naturally turned on archæology, and, mentioning having visited the ruined cities of Ceylon, he said it was just ' a toss up' whether he had gone to Ceylon or Central America to excavate. Immediately after luncheon 